\title{
The petrology and sulphur isotopic composition of sulphide and sulphate in the Kimberley kimberlites
}

\author{
ANGUS FitzPAYNE ${ }^{1}$, ANDREA GIULIANI ${ }^{1,2}$, NIVEA \\ MAGALHAES $^{3,4}$, ASHTON SOLTYS ${ }^{2}$, MARCO \\ FIORENTINI $^{5}$, JAMES FARQUHAR ${ }^{3}$ \\ ${ }^{1}$ Institute for Geochemistry and Petrology, ETH Zurich \\ ${ }^{2}$ School of Earth Sciences, University of Melbourne \\ ${ }^{3}$ Department of Geology, University of Maryland \\ ${ }^{4}$ Department of Earth Sciences, University of Toronto \\ ${ }^{5}$ School of Earth Sciences, University of Western Australia
}

The petrology and bulk-rock sulphur isotopic compositions of kimberlite samples from four localities (Bultfontein, De Beers, Kimberley, Wesselton) of the archetypal Kimberley cluster, South Africa, were used to investigate the origin(s) of $\mathrm{S}$ in kimberlites and gain insights into the occurrence of recycled crustal material in the source of Mesozoic kimberlites. The samples, which show variable degrees of alteration, are all hypabyssal and were derived from coherent root-zones as well as dykes and sills. Typical sulphide minerals are $\mathrm{Cu}-\mathrm{Fe}-\mathrm{Ni}$-sulphides with less common pyrite, galena, sphalerite, and djerfisherite. They occur in a variety of textural associations, for example as groundmass phases, secondary inclusions in olivine, inclusions in matrix phases (e.g., phlogopite), or in carbonate-serpentine segregations. Barite is the most commonly observed sulphate phase.

Bulk-sample $\delta^{34} \mathrm{SVCDT}_{\mathrm{V}}$ values of sulphides in fresh kimberlites, which mostly do not contain barite, vary from 2.0 to $-5.7 \%$. Slightly altered kimberlite samples, in which sulphides were generally associated with serpentine, returned somewhat higher bulk-sulphide $\delta^{34} \mathrm{~S}$ VCDT $(-3.8$ to $+1.1 \%$ ). One sample from the Wesselton Water Tunnel Sills complex contains abundant barite and pyrite in its groundmass, with the latter having $\delta^{34} \mathrm{~S}_{\mathrm{VCDT}}(+0.2$ to $+1.9 \%)$ similar to altered kimberlites. Two further altered samples returned $\delta^{34} \mathrm{SVCDT}_{\mathrm{V}}$ values $(-10.1$ to $-13.0 \%$ ) that suggest a contribution from the local country rocks (Dwyka shale: ${ }^{34} \mathrm{~S}_{\mathrm{VCDT}}$ from -10.2 to $-10.5 \%$ ). All samples have near-zero $\Delta^{33} \mathrm{~S}$ values, suggesting that material displaying mass-independent fractionation has not played an important role. The negative $\delta^{34} S_{\text {VCDT }}$ values of fresh kimberlites from Kimberley suggest the involvement of recycled crustal material in their source, which is consistent with radiogenic isotope compositions. Overall, it appears that most kimberlitic sulphide $\mathrm{S}$ isotopic compositions can be explained by the action of a few typical magmatic/hydrothermal processes. 